\section{Isozyme Variation in Cultivars of Purple Loosestrife (Lythrum sp.)}

\author{
Mark S. Strefeler and Elizabeth Darmo ${ }^{1}$ \\ Department of Horticultural Science, University of Minnesota, 305 Alderman \\ Hall, 1970 Folwell Avenue, Saint Paul, MN 55108

\section{Roger L. Becker and Elizabeth J. Katovich \\ Department of Agronomy and Plant Genetics, University of Minnesota, 411 Borlaug Hall, 1911 Buford Circle, Saint Paul, MN 55108}

Additional index words. genetic fingerprinting, Lythrum salicaria, Lythrum virgatum, weed control

\begin{abstract}
Isozyme markers were used to identify several cultivars of purple loosestrife (Lythrum spp.) and interspecific hybrids. There were three zones of activity for phosphoglucomutase (PGM) and phosphoglucoisomerase (PGI) and two zones for malate dehydrogenase (MDH) in purple loosestrife cultivars. Allelic constitution could not be characterized due to the polyploid nature of purple loosestrife and the possibility of intergenic dimerization. Coefficients of genetic similarity were used to estimate the degree of relationship between purple loosestrife cultivars. Cluster analysis indicated that seven cultivars originating from $L$. salicaria $L$. were not distinguishable from eight cultivars originating from $L$. virgatum $L$., indicating possible limitations of isozyme analysis for cultivar differentiation based on species origin. All but two cultivars ('Morden Gleam' and 'Morden Rose') could be distinguished from one another by isozyme phenotype. This result suggests that isozymes may be useful for cultivar fingerprinting if additional isozyme systems could be resolved. 'Robert' appeared morphologically heterogeneous, and plants could be differentiated based on isozyme banding patterns. Also, two putative clones of 'Stichflamme' (one marketed under its English synonym 'Fire Candle') possessed distinct isozyme phenotypes, indicating a lack of clonal integrity.
\end{abstract}

Purple loosestrife is a popular garden plant species introduced to the United States from Europe in the 1800s. It often escapes cultivation into nearby wetlands and establishes itself along edges of rivers and ponds; in roadside ditches; in low, wet meadows and marshes; and other disturbed sites (Stuckey, 1980). Purple loosestrife displaces native, sometimes rare, wetland species and destroys wetland ecosystems because it has little value as a food or nesting site for wildlife (Rawinski and Malecki, 1984; Smith, 1964).

Purple loosestrife has infested 8100 ha in Minnesota (Anderson and Ascher, 1993), 12,000 ha in Wisconsin (Woehler and Henderson, 1986), >1200 ha in Ohio (Balogh

Received for publication 13 Mar. 1995. Accepted for publication 29 Nov. 1996. Scientific Journal Series paper no. 21,740 of the Minnesota Agricultural Expt. Station, St. Paul. We thank the Legislative Commission on Minnesota Resources for partial support of this work through the Minnesota Dept. of Natural Resources. We also thank Jay Rendall, Ellen Fuge, and Luke Skinner for their assistance, direction, and support. Heather Kreidermacher and Dan Augustine helped with lab work, and Peter Ascher and Neil Anderson provided plant materials and helped interpret the isozyme gels. The cost of publishing this paper was defrayed in part by the payment of page charges. Under postal regulations, this paper therefore must be hereby marked advertisement solely to indicate this fact. ${ }^{1}$ Current address: Carolina Biologicals, 2700 York Rd., Burlington, NC 27215. and Bookhout, 1989), and an even larger land area in New York. In response to its alarming spread, Minnesota, Illinois, Indiana, Ohio, Washington, and Wisconsin have enacted legislation that restricts or prohibits the sale or cultivation of purple loosestrife (Cutright, wDisputed parentage; also classified as $L$. virgatum.

"Dwarf cultivars with L. alatum in their pedigrees.
1986; Ithaca Journal, 1989). Many of these laws focus on cultivars of $L$. salicaria but do not restrict sale of $L$. virgatum cultivars because these are not deemed to be a threat to wetland habitats.

Lythrum salicaria and L. virgatum are polyploid tristylous (Nicholls, 1986) and intermate freely. Morphological characteristics used to distinguish L. salicaria, L. virgatum, and their hybrids are suspect (Cutright, 1978, 1986); however, a few cultivars have been distinguished in a few populations (Ottenbreit, 1991). Thus, we and several North American taxonomists (Rendall, 1989) consider L. salicaria and $L$. virgatum to be the same species.

Little is known about the genetic relationship between $L$. salicaria and $L$. virgatum cultivars. Isozyme analysis may provide valuable information regarding genetic diversity present in purple loosestrife. Three enzyme systems provide allozymes useful for determining the genetic relationships among weedy populations of purple loosestrife, native populations of $L$. alatum, and cultivars of $L$. salicaria and L. virgatum (Strefeler et al., 1995). Weedy populations were genetically similar to $L$. salicaria and $L$. virgatum cultivars, suggesting that $L$. salicaria and $L$. virgatum may be involved in the evolution of weedy purple loosestrife in the United States.

Genetic proximity coefficients (i.e., similarity coefficients) offer means to analyze variation in several traits simultaneously (Sneath and Sokal, 1973). For each individual, a proximity value is computed with every other individual in the study. These values are used to construct a symmetric proximity matrix. Cluster analysis then can be used to depict the relationships among individuals in one or more dimensions (Beer et al., 1993). This method clarifies genetic relationships among populations.

Table 1. Isozyme banding patterns for several Lythrum cultivars of diverse origin.

\begin{tabular}{|c|c|c|c|c|}
\hline \multirow[b]{2}{*}{ Cultivar } & \multirow{2}{*}{$\begin{array}{l}\text { Putative } \\
\text { origin }^{y}\end{array}$} & \multicolumn{3}{|c|}{ Isozyme banding pattern $^{z}$} \\
\hline & & PGI & PGM & $\mathrm{MDH}$ \\
\hline Fire Candle (synonym: Firecandle) ${ }^{\mathrm{x}}$ & S & $\mathrm{C}$ & $\mathrm{F}$ & $\mathrm{B}$ \\
\hline Stichflamme & $\mathrm{S}$ & $\mathrm{N}$ & $\mathrm{C}$ & A \\
\hline Flash Fire (synonym: Feuerkerze) & $\mathrm{S}$ & G & $\mathrm{C}$ & $\mathrm{B}$ \\
\hline Happy & $\mathrm{S}$ & A & A & B \\
\hline Roseum Superbum & $\mathrm{S}$ & $\mathrm{H}$ & $\mathrm{H}$ & B \\
\hline The Beacon & $\mathrm{S}$ & M & $\mathrm{J}$ & B \\
\hline Gypsy Blood (synonym: Zigeunerblut) & $\mathrm{S}$ & $\mathrm{I}$ & $\mathrm{D}$ & $\mathrm{B}$ \\
\hline Robert (R1) $)^{\mathrm{w}, \mathrm{v}, \mathrm{u}}$ & $\mathrm{S}$ & $\mathrm{I}$ & A & $\mathrm{B}$ \\
\hline Robert (R2) & $\mathrm{S}$ & $\mathrm{I}$ & A & B \\
\hline Robert (R3) & $\mathrm{S}$ & $\mathrm{J}$ & $\mathrm{D}$ & B \\
\hline Robert (R4) & $\mathrm{S}$ & $\mathrm{I}$ & A & B \\
\hline Robert (R5) & $\mathrm{S}$ & $\mathrm{K}$ & A & B \\
\hline Purple Dwarf ${ }^{u}$ & V & $\mathrm{E}$ & B & B \\
\hline Morden Pink & V & M & I & B \\
\hline Morden Rose ${ }^{t}$ & V & $\mathrm{L}$ & I & B \\
\hline Morden Gleam ${ }^{\mathrm{t}}$ & $\mathrm{V}$ & $\mathrm{L}$ & I & B \\
\hline Pink Spires & V & $\mathrm{D}$ & B & B \\
\hline Purple Spires & V & $\mathrm{F}$ & $\mathrm{G}$ & B \\
\hline Rose Queen & $\mathrm{V}$ & $\mathrm{B}$ & $\mathrm{E}$ & B \\
\hline Dropmore Purple & V & $\mathrm{I}$ & $\mathrm{C}$ & B \\
\hline
\end{tabular}

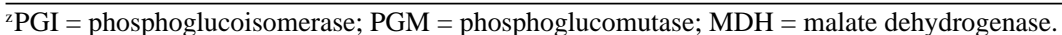
${ }^{\mathrm{y}} \mathrm{S}=$ L. salicaria and $\mathrm{V}=$ L. viratum; banding patterns designated $\mathrm{A}$ to $\mathrm{N}$ are illustrated in Fig. $1 \mathrm{~A}-\mathrm{C}$. 'Two clones of 'Fire Candle' (one sold as 'Stichflamme' and listed separately) were assayed.

'Five clones of 'Robert' (obtained from separate sources and listed separately) were assayed.

'Interspecific hybrid cultivars derived from the cross 'Morden Pink' x L. alatum. 
Our objectives were to identify polymorphic isozyme banding patterns, to use these patterns to distinguish cultivars, and to examine the relationships among purple loosestrife cultivars.

\section{Materials and Methods}

Plant collection and propagation. Clones of 16 purple loosestrife cultivars, eight putatively identified as L. salicaria and eight of putative $L$. virgatum origin, were obtained from commercial nurseries (Table 1). Five clones of 'Robert' from several commercial sources (identified in this study as R1 to R5) and two clones from several sources of 'Stichflamme' (one sold under the English name 'Fire Candle' and the other sold as 'Stichflamme') were included to gain insight into clonal integrity of Lythrum cultivars. Plants were grown in the greenhouse at a mean of 21C and under a 16-h photoperiod (Shamsi and Whitehead, 1974). Natural lighting was supplemented with irradiance from fluorescent lamps at $200 \mu \mathrm{mols} \cdot \mathrm{m}^{-2} \cdot \mathrm{s}^{-1}$, and plants were continuously subirrigated in 2 to $5 \mathrm{~cm}$ of water and fertilized as needed to ensure adequate growth.

Tissue sample collection and extraction. Plant tissue was sampled from newly expanded leaves of five plants of each cultivar, placed on ice, and refrigerated until ground in extraction buffer ( $<15 \mathrm{~min})$. Enzyme extraction was performed in a cold room at $4 \mathrm{C}$ by homogenizing 50 to $100 \mathrm{mg}$ of leaf tissue in two to four drops of cold extraction buffer (Morden et al., 1987). The homogenate was loaded on paper wicks (Whatman, 3-mm, chromatography paper), and wicks were placed in microfuge tubes and stored at $-80 \mathrm{C}$ until used.

Gel preparation and staining. Starch gels (13\%) were prepared with $65 \mathrm{~g}$ starch agar (Starch Art Corp., Smithville, Texas) and $15 \mathrm{~g}$ sucrose in $500 \mathrm{ml}$ of heated gel buffer, degassed by vacuum aspiration, poured into gel molds, covered with glass, and allowed to set for $24 \mathrm{~h}$. Electrophoresis was conducted using an electrode buffer of $0.065 \mathrm{M} \mathrm{L}$-histidine and 0.019 m citric acid at pH 5.7 (Stuber et al., 1977). Samples were electrophoresed for 7.25 $\mathrm{h}$ at $17 \mathrm{~W}$.

Gels were sliced and assayed for phosphoglucoisomerase (PGI), phosphoglucomutase (PGM), and malate dehydrogenase (MDH) activity using staining techniques described by Gottlieb (1981).

Bands could not be assigned to specific loci due to the polyploid nature of Lythrum, the possible formation of intergenic dimers, and the lack of inheritance data for these enzyme systems. Thus, band patterns from each zone were scored as unordered multistate traits (Beer et al., 1993; Hancock and Bringhurst, 1979). Bands ( $1=$ present and $0=$ absent) and zones of activity were numbered in ascending order starting with the fastest migrating band (farthest from origin) for each enzyme system. To obtain estimates of genetic similarity among cultivars, coefficients of similarity were computed from the presence or absence of bands using the simple matching

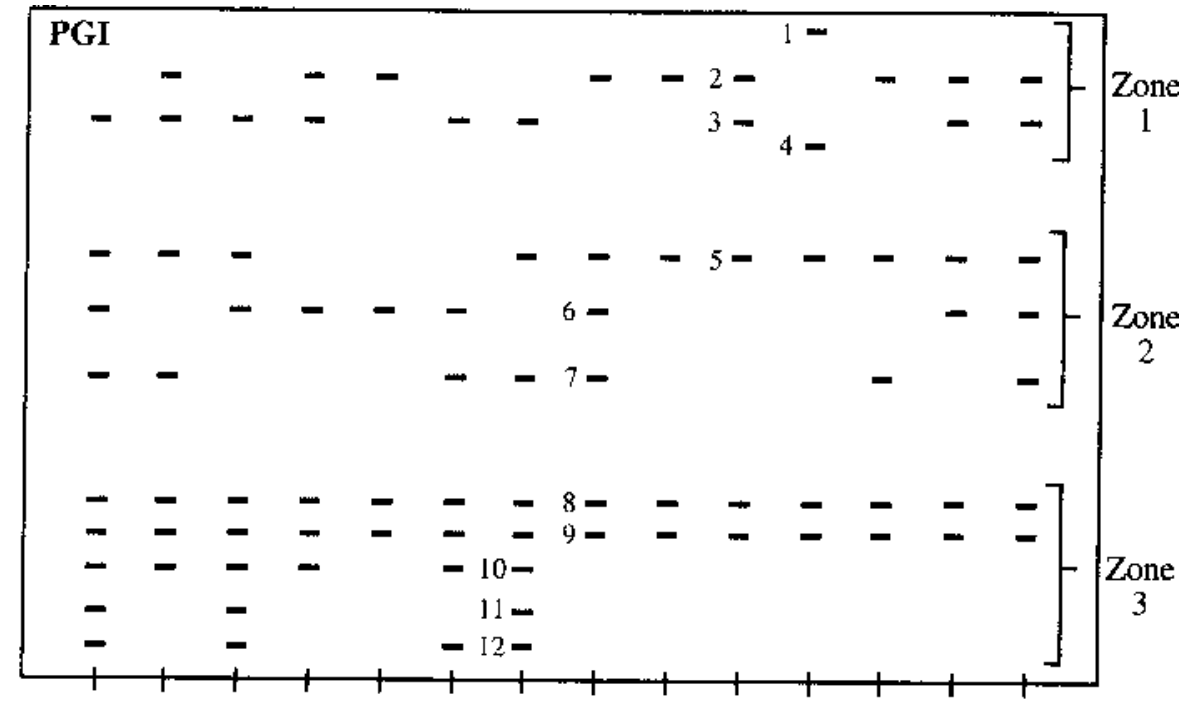

$\begin{array}{llllllllllllll}\text { A } & \text { B } & \text { C } & \text { D } & \text { E } & \text { F } & \text { G } & \text { H } & \text { I } & \text { J } & \text { K } & \text { L } & \text { M } & \text { N }\end{array}$

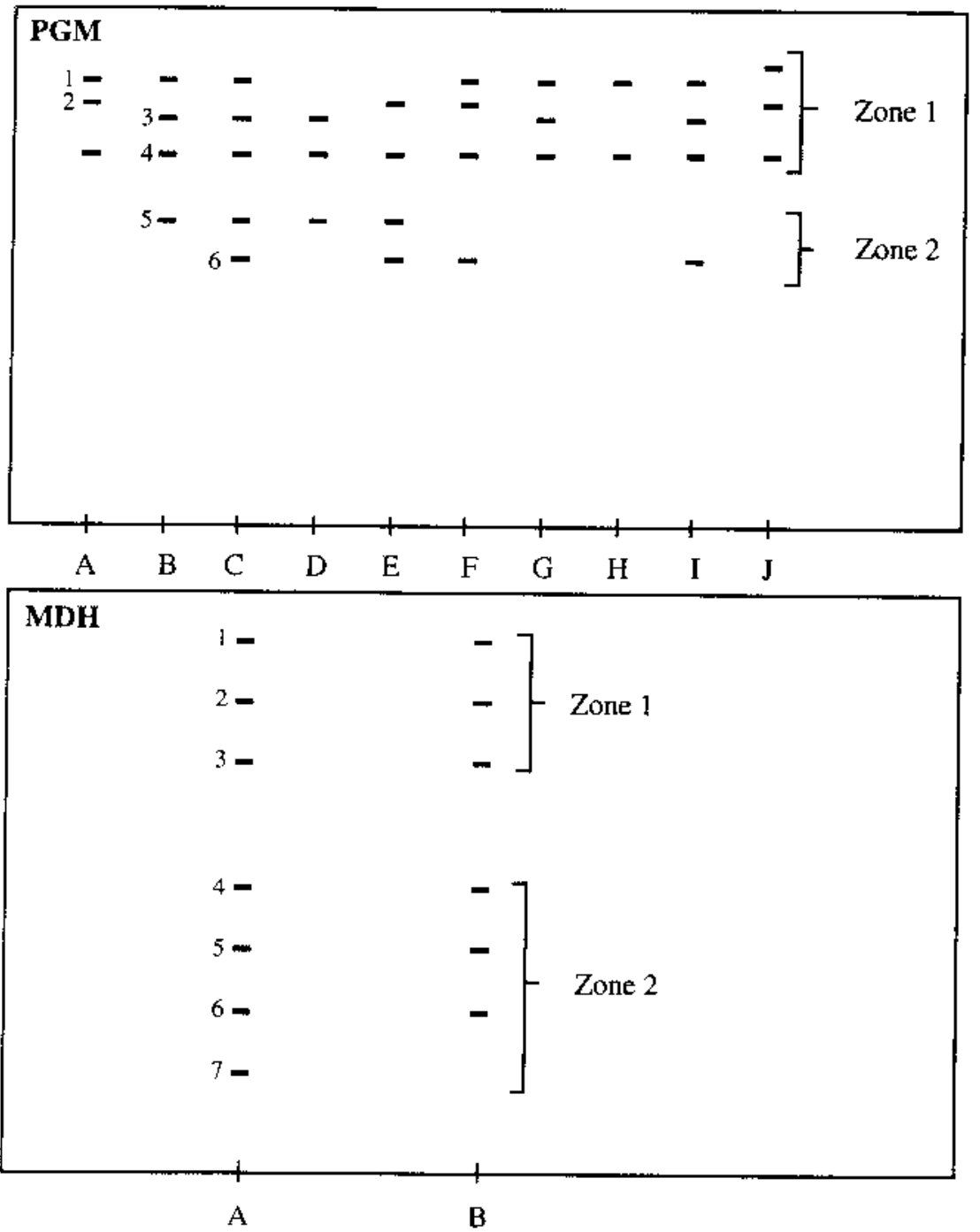

Isozyme Banding Pattern

Fig. 1. Illustration of starch gels showing isozyme phenotypes of seven Lythrum salicaria cultivars and eight L. virgatum cultivars for phosphoglucoisomerase (PGI), phosphoglucomutase (PGM), and malate dehydrogenase (MDH). Bands were numbered in ascending order based on mobility of protein starting with the fastest migrating band (the band farthest from the origin). 
method (SM) of the NT-SYS (Exeter Software, Setauket, N.Y.) (Clifford and Stephenson, 1975). The resultant proximity matrix then was used in the SAHN clustering procedure of NT-SYS (UMPGA) to produce dendrograms depicting the relationships among cultivars.

\section{Results}

The enzyme systems used provided adequate resolution to allow scoring of more than one zone of activity in each enzyme system (Table 1). These zones of activity were likely products of different loci. Twelve bands and three zones of activity resulted for PGI (Fig. 1A). Two bands were present in all cultivars (bands 8 and 9), and two bands in zone 1 were unique to the 'Robert' clone, R5 (band 1). All cultivars, except 'Morden Gleam' and 'Morden Rose', were distinguishable by their isozyme phenotypes using PGI, PGM, and $\mathrm{MDH}$. Six bands and two zones of activity for PGM developed (Fig. 1B). Band 4 (zone 1) was monomorphic. Seven bands and two zones of activity resulted from individuals assayed for MDH (Fig. 1C). All bands were monomor- phic at both putative loci for all cultivars, except 'Stichflamme', which had an additional band (band 7). This band was not absent in the clone sold as 'Fire Candle', the English synonym for 'Stichflamme'.

Five clones of 'Robert' from five commercial sources were compared using isozymes. Three of the five clones (R1, R2, and R4) had the same banding pattern. The remaining clones (R3, R5) had unique banding patterns. Clone R3 had distinct banding patterns for PGM and PGI (Fig. $1 \mathrm{~A}$ and B), and clone R5 had a unique banding pattern for PGI (Fig. 1A). Two clones of 'Stichflamme' from different commercial sources also differed in banding patterns. One was sold as 'Stichflamme', and the second was sold as 'Fire Candle'. These clones exhibited distinct banding patterns for PGM, PGI, and MDH (Fig. 1). 'Stichflamme' had a unique band (band 7) for MDH that distinguished it from all other cultivars (Fig. 1C).

\section{Discussion}

Fourteen of the sixteen cultivars could be distinguished by PGM, PGI, and MDH; the cultivars that could not be distinguished using these isozyme systems were 'Morden Gleam' and 'Morden Rose'. These cultivars are fullsibs from the interspecific cross 'Modern Pink' $x$ L. alatum. Thus, they would be expected to differ at fewer putative loci, and more markers would be necessary to distinguish these cultivars.

Cluster analysis on the coefficients of similarity for cultivars revealed one major cluster (Fig. 2). This result indicates that the $L$. salicaria and $L$. virgatum cultivars were not genetically distinct.

As with the morphological traits examined by Anderson and Ascher (1993), we did not find any species-specific markers that could be used to reliably distinguish between species. In a previous study, the five clones of 'Robert' that we used differed for at least one morphological marker (Anderson and Ascher, 1993), and we found differences in isozyme banding patterns for three of the five clones. In addition, two clones of 'Stichflamme', one identified by its English synonym, 'Fire Candle', were genetically distinct from each other. These results indicate the inaccurate identification and mislabeling of cultivars in this species. 'Robert' represented an extreme

\section{Relative genetic similarity}
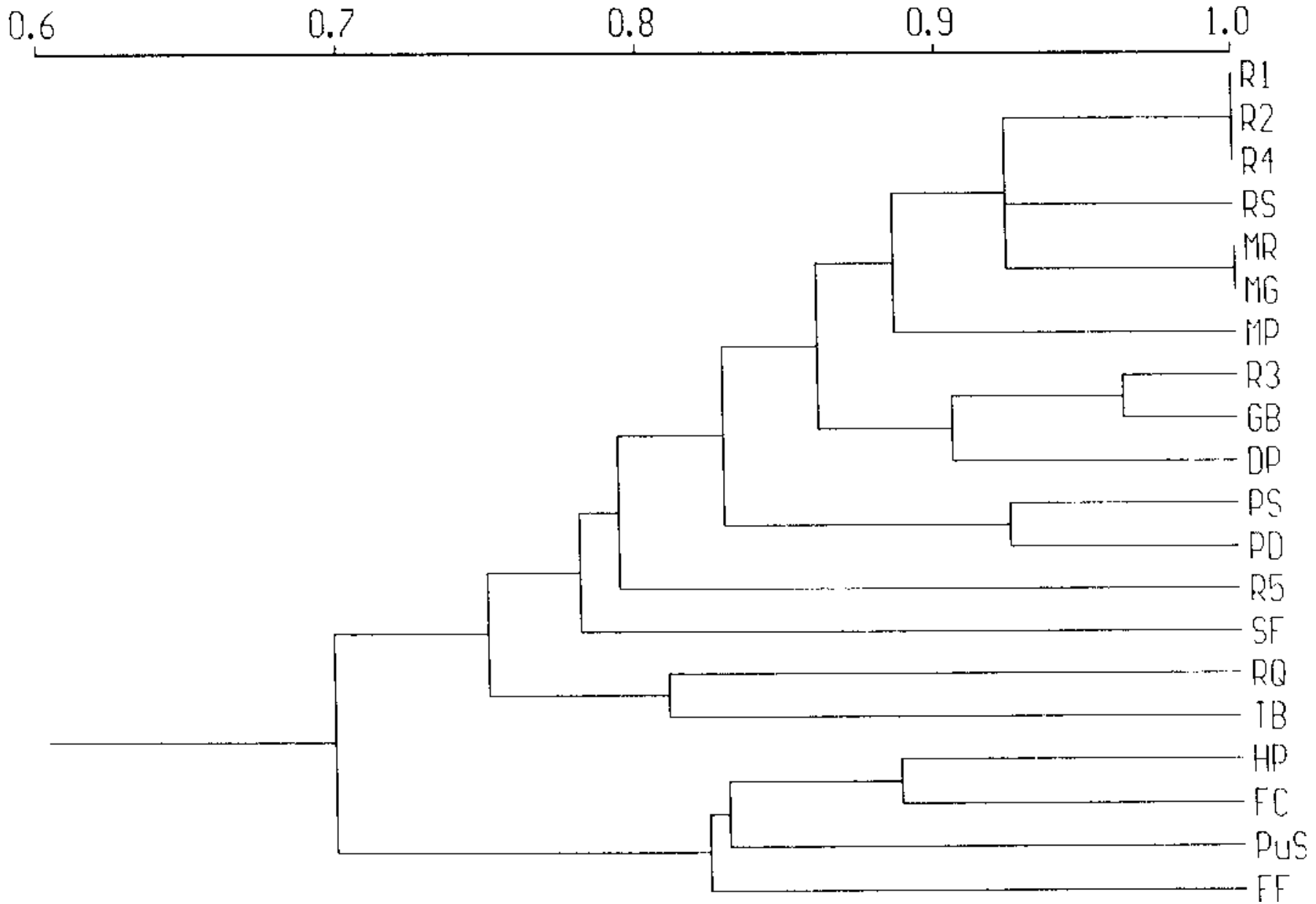

Fig. 2. Dendrogram of genetic similarity (where $0=$ no similarity for traits scored and $1=$ complete similarity) constructed from proximity matrix coefficients based on isozyme phenotypes of seven Lythrum salicaria and eight $L$. virgatum cultivars. Abbreviations: 'Dropmore Purple' = DP; 'Fire Candle' = FC; 'Flash Fire' = FF; 'Gypsy Blood' = GB; 'Happy' = HP; 'Morden Gleam' = MG; 'Morden Pink' = MP; 'Morden Rose' = MR; 'Pink Spires' = PS; 'Purple Dwarf' = PD; 'Purple Spires' = PuS; 'Robert' (clones 1, 2, 3, 4, 5) = R1, R2, R3, R4, R5, respectively; 'Rose Queen' = RQ; 'Roseum Superbum' = RS; 'Stichflamme' = SF; and 'The Beacon' $=$ TB. 
example of the lack of clonal integrity of cultivars, with all five clones differing for at least one morphological marker (Anderson and Ascher, 1993) and three of the five differing for isozyme banding pattern.

Some states have prohibited only the sale and cultivation of $L$. salicaria on the basis that $L$. virgatum is not a threat to wetland ecosystems. Our results and those of Anderson and Ascher (1993) suggest that this is not a viable strategy because taxonomic confusion has made it difficult to distinguish these species based on morphological characteristics or isozymes. In a previous study using isozymes, we reported that the genetic similarity between weedy purple loosestrife and cultivars, regardless of species origin, was moderate to high [mean of Hedrick's $I=0.77$ and 0.81 for L. salicaria and $L$. virgatum cultivars, respectively (Strefeler, et al., 1995)], indicating that L. virgatum cultivars might be progenitors of weedy purple loosestrife. Based on these findings, the most ecologically sound strategy to prevent the spread of purple loosestrife would be to prohibit the distribution and sale of all cultivars.

Individual purple loosestrife cultivars ( $L$. salicaria and $L$. virgatum) can be differentiated based on isozyme banding patterns. However, due to clonal variation, each stock plant must be individually fingerprinted to ensure proper identification. This process is cumbersome and costly, and, therefore, isozyme analysis does not offer a economically viable means of species identification for the nursery trade.

\section{Literature Cited}

Anderson, N.O. and P.D. Ascher. 1993. Male and female fertility of loosestrife (Lythrum) cultivars. J. Amer. Soc. Hort. Sci. 118:851-858.

Balogh, G.R. and T.A. Bookhout. 1989. Purple loosestrife (Lythrum salicaria) in Ohio's Lake Erie marshes. Ohio J. Sci. 89:62-64.

Beer, S.C., J. Goffreda, T.D. Phillips, J.P. Murphy, and M.E. Sorrells. 1993. Assessment of genetic variation in Avena sterilis using morphological traits, isozymes, and RFLPs. Crop Sci. 33:13861393.

Clifford, H.T. and W. Stephenson. 1975. An introduction to numerical classification. Academic, New York.

Cutright, N.J. 1978. Purple loosestrife: Beautiful, exotic, or unwanted weed? Wis. Nat. Res. 2:2627.

Cutright, N.J. 1986. Regulation of purple loosestrife by states in the Midwest. Proc. North Central Weed Control Conf. 41:123-125.

Gottlieb, L.D. 1981. Electrophoretic evidence and plant populations. Program Phytochemistry 7:146.

Graham, S.A. 1975. Taxonomy of Lythraceae in the southeastern United States. SIDA 6:80-103.

Hancock, J.F., Jr., and R.S. Bringhurst. 1979. Ecological differentiation in perennial octoploid species of fragaria. Amer. J. Bot. 66:367-375.

Hedrick, P.W. 1971. A new approach to measuring genetic similarity. Evolution 25:276-280.

Ithaca Journal. 1989. Flower is pretty and also a problem: Plant is damaging delicate wetlands. Ithaca J. August 18:7A.

Morden, C., J. Doebley, and K. Schertz. 1987. A manual of techniques for startch gel electrophoresis of sorghum isozymes. Texas Agr. Expt. Sta., MP-1635, College Station.
Nicholls, M.S. 1986. Pollen flow, self-pollination and gender specialization: Factors affecting seedset in the tristylous species Lythrum salicaria (Lythraceae). Plant Systematics Evolution 156:151-157.

Ottenbreit, K.A. 1991. The distribution, reproductive biology, and morphology of Lythrum species, hybrids and cultivars in Manitoba. MS Thesis, Univ. of Manitoba, Winnipeg, Canada.

Rawinski, T.J. and R.A. Malecki. 1984. Ecological relationships among purple loosestrife, cattail and wildlife at the Montezuma National Wildlife Refuge. N.Y. Fish Game J. 31:81-87.

Rendall, J. 1989. The Lythrum story: A new chapter. Minn. Hort. 117:22-24.

Shamsi, S.R.A. and F.H. Whitehead. 1974. Comparative eco-physiology of Epilobium hirustum L. and Lythrum salicaria. II. Growth and development in relation to light. J. Ecol. 62: 631-645.

Smith, R.H. 1964. Experimental control of purple loosestrife (Lythrum salicaria L.). N.Y. Fish Game J. 11:35-46.

Sneath,P.H.A. and R.R. Sokal. 1973. Numerical taxonomy. W.H. Freeman and Co., San Francisco.

Strefeler, M.S., E. Darmo, R.L. Becker, and E.J. Katovich. 1996. Isozyme characterization of genetic diversity in Minnesota populations of purple loosestrife, Lythrum salicaria (Lythraceae). Amer. J. Bot. (In press.)

Stuber, C.W., M.M. Goodman, and F.M. Johnson. 1977. Genetic control and racial variation of $\beta$ glucosidase isozymes in maize (Zea mays $\mathrm{L}$.). Biochemistry Genet. 15:383-394.

Stuckey, R.L. 1980. Distributional history of Lythrum salicaria (purple loosestrife) in North America. Bartonia 47:3-20.

Woehler, E.E. and R.A. Henderson. 1986. Distribution of purple loosestrife in the Midwest. Proc. North Central Weed Control Conf. 41:129. 